Educational Research for Social Change (ERSC)

Volume 10 No. 2 September 2021

pp. 105-123

ersc.nmmu.ac.za

ISSN: 2221-4070

\title{
Teachers' Experiences in the Implementation of the Life Skills CAPS for Learners With Severe Intellectual Disability ${ }^{1}$
}

\author{
Julialet Rens \\ ORCID No: 0000-003-2727-2834 ID \\ COMBER, Faculty of Education, \\ North-West University \\ Julialet.Rens@nwu.ac.za
}

\author{
Hannelie Louw \\ ORCID No: 0000-0003-2314-4464 ID \\ COMBER, Faculty of Education, \\ North-West University \\ Hannelie.Louw@nwu.ac.za
}

\begin{abstract}
This article focuses on a participatory process where the experiences of teachers regarding the implementation of the life skills curriculum and assessment policy statement (CAPS) for learners with severe intellectual disabilities (SID) in schools for learners with special educational needs were investigated. This curriculum for learners with SID has been developed to be more effective in meeting the needs of these learners. The curriculum ensures that learners can meet the requirements of the national CAPS used in ordinary public schools at a reduced depth and width, or at a more functional level, in accordance with their cognitive abilities. Although a descriptive mixed research method was applied in the study, this article reports on the qualitative part of the research. In the qualitative phase, collages and arts-based discussions with core project groups were used to generate data. Four schools, 13 core project groups, and 51 participants (teachers) were involved in the research. The transcribed data from the core project group discussions were analysed using thematic analysis, and the themes that emerged were discussed by the participants. Based on the results of these qualitative arts-based discussions, the findings were used to create opportunities for the teachers to talk and work together to jointly develop a training manual for beginner teachers and to form a learning environment that would permit rich inquirybased dialogue among the teachers.
\end{abstract}

Keywords: CAPS, curriculum development, life skills, special needs curriculum, special schools

Copyright: (C) 2021 Rens and Louw

This is an open access article distributed under the terms of the Creative Commons Attribution NonCommercial License, which permits unrestricted non-commercial use, distribution, and reproduction in any medium, provided the original author and source are credited.

\footnotetext{
${ }^{1}$ Ethical clearance number: NWU-00355-18-A2
} 
Please reference as: Rens, J. and Louw, H. (2021). Teachers' Experiences in the Implementation of the Life Skills CAPS for Learners With Severe Intellectual Disability. Educational Research for Social Change, 10 (2), 105-123. http://dx.doi.org/10.17159/2221-4070/2021/v10i2a7

\section{Introduction}

Prior to 1994, learners in South Africa were divided not only according to race, but also according to disability or ability (Engelbrecht, 2020). Walton and Rusznyak (2014) noted that in the previous dispensation, there was a well-resourced special education system for white learners with special educational needs. One of the key issues the South African government wanted to address after 1994 was the discriminatory and exclusionary educational practices against children with severe and profound disabilities - by placing learners in inclusive settings according to their disabilities and not according to race. This was done through the introduction of the Education White Paper 6: Special Education Needs-Building an Inclusive Education System (EWP6; Department of Education, 2001), which declared that the state has an obligation to protect the basic human rights of children without discriminating on race, class, gender, creed, or age. Children must have the opportunity to develop their talents and abilities in order to contribute to society in a meaningful way.

Thus, "inclusive education" can be broadly defined as the process by which learners who were previously taught in a separate special education system because of their barriers to learning are now taught in ordinary schools that accept responsibility to change and improve to provide the support needed to ensure access and participation for all learners (Department of Education, 2001). In addition to EWP6, Section 5 of the South African Schools Act $(1996$, p. 8) affirmed that a "public school must admit learners and serve their educational requirements without unfairly discriminating in any way." Section 12(4) of this Act declared: "The member of the Executive Council must, where reasonably practicable, provide education for learners with special educational needs at ordinary public schools and provide relevant educational support services for such learners" (South African Schools Act, 1996, p. 10).

There are some critical international events in the movement towards inclusive education that also influenced the transformation of the South African education system. The Salamanca Statement (UNESCO, 1994) affirmed that it was discriminatory to refuse learners with special educational needs admission to regular education settings. The transformation of schools to cater for all learners and to introduce an inclusive education approach was encouraged through this statement. Furthermore, the United Nations' (2006) Convention on the Rights of Persons with Disabilities promoted inclusive education for learners with severe intellectual disabilities (SID), and has gained a lot of ground and support around the world in the past few decades (Chowdhury, 2011). However, it is important to emphasise that inclusive education is not only about placing learners with disabilities in ordinary public schools but also includes thinking wisely about multiple facets of education such as assessment, access, support, resources, and leadership (Mitchell, 2015). In addition, research has shown that the implementation of such an inclusive education system continues to be challenging-specifically regarding an appropriate curriculum for learners with SID (Engelbrecht, 2020).

This article focuses on the experiences of teachers in the implementation of the Differentiated Curriculum and Assessment Policy Statement: Life Skills (hereafter, Life Skills CAPS for Learners with SID; Department of Basic Education [DBE], 2017a) ${ }^{2}$ in schools for learners with special educational needs. The American Psychiatric Association (2020) stated that SID involve problems with general mental abilities that affect functioning in two areas: intellectual functioning (e.g., learning, problem

\footnotetext{
${ }^{2}$ Although this document is available by request from the Department of Basic Education, it is still under review by the Department, and will only be generally available when it is declared a policy.
} 
solving, and judgement) and adaptive functioning (activities of daily life, e.g., communication and living independently).

The writing of the differentiated CAPS for Learners with SID originated from a judgement delivered in the court case, Western Cape Forum for Intellectual Disability v. Government of the Republic of South Africa (2010). In the judgement, it was stated that the Western Cape DBE had failed to meet the educational needs of severely and profoundly intellectually disabled children, which was a breach of the children's rights to basic education, fairness, and protection from neglect or humiliation. The South African government had to take reasonable measures to protect severely or profoundly disabled learners in the Western Cape to ensure their access to quality basic education (Western Cape Forum for Intellectual Disability v. Government of the Republic of South Africa, 2010). The writing of an adjusted SID curriculum based on the CAPS was approved in 2013 by the Minister of Basic Education (M. Schoeman, personal communication, 26-28 October, 2017). The CAPS for Learners with SID was implemented in pilot schools in 2018. After the implementation in pilot schools, other schools for learners with special educational needs also began to implement the CAPS for Learners with SID. The first round of public comment was written at the end of 2018 (C. Vlachos, personal communication, October 14, 2020).

With the implementation of the SID curriculum, teachers experienced various challenges, for example, limited resources, extremely heavy workloads, and too much assessment for each subject. These challenges were discussed during training sessions and in the public comment session (C. Vlachos, personal communication, October 14, 2020). These challenges are consistent with what international research has found regarding the implementation of a new curriculum. In New Zealand, Australia, England, and the United States of America, the implementation of new curricula has led to an increase in the workload of teachers (Ingvarson et al., 2005). According to van Tonder and Fourie (2015), 28\% of teachers in New Zealand have considered leaving the teaching profession due to the workload. This article reports on a collaborative investigation into challenges experienced by teachers in schools for learners with SID.

\section{Theoretical Perspective}

Given that it is important to build research on a theoretical perspective, Paulo Freire's (2005) humanising approach was applied to this research. Freire (2005) stated that curriculum planning is a process where people are the starting point; it is a human-orientated process that involves people, their expectations, and their needs (Mahmoudi \& Babae, 2014). Curriculum planning is, according to Freire (2005), a continual and participative process in which all stakeholders (teachers, learners, and experts) involved in teaching and learning should play a role. The Life Skills CAPS for Learners with SID was written by teachers in schools for learners with special needs to take into account their specific needs (DBE, 2017a). Thereafter, it was reviewed and approved by subject specialists from the DBE (C. Vlachos, personal communication, October 14, 2020). This corresponds with Freire's statement that curriculum planning should not be a top-down process (as cited in Mahmoudi \& Babae, 2014).

According to Freire (2005), curricula can either liberate or domesticate groups in society. In this case, the Life Skills CAPS for Learners with SID aims at liberating these learners. This is evident given that the curriculum for learners with SID was launched to strengthen respect for human rights, fundamental freedom, and human diversity. It aims to provide learners in ordinary schools and in schools for learners with special educational needs across the spectrum with competencies and aptitudes that ensure dignity, self-assurance, and active participation in the school and the community (DBE, 2017a). 


\section{Contextualisation of the Curriculum for Learners With SID}

In South Africa, a new school curriculum was introduced in 1997, namely Curriculum 2005 (Department of Education, 1997). This curriculum was grounded in an outcomes-based approach and was specifically developed to address the learning paces of all learners, including those with disabilities. However, after several reviews, the curriculum was adapted to become the National Curriculum Statement (NCS) CAPS (DBE, 2011). It was evident that schools for learners with special educational needs struggled with adapting the CAPS, and that is why the DBE gave the instruction to form a working group for SID with the goal to formally adapt the NCS CAPS to the CAPS for Learners with SID (M. Schoeman, personal communication, 26-28 October, 2017).

Table 1 illustrates the differences between the two curriculum documents as developed by Schoeman (personal communication, 29 September-3 October, 2014) during the first writing session for the curriculum for SID learners in 2014.

Table 1

Differences between the NCS CAPS and the CAPS for Learners with SID

\begin{tabular}{ll}
\hline NCS CAPS & SID CAPS \\
\hline 13 years of education & 14 years of education \\
\hline Grades are not subdivided & Grades are subdivided into 2 or 3 years \\
\hline Each grade equals 1 year & Each grade equals more than 1 year \\
\hline Learners receive a National Senior Certificate & Learners receive a Certificate of Attainment \\
\hline Grade 9 equals Level 1 on the NQF & Grade 6 is below Level 1 on the NQF \\
\hline Learners may enter a TVET college after they & Learners with potential may enter the Technical \\
have completed Grade 9 successfully & Occupational Stream when they turn 15 \\
\hline Learner instruction time per 5-day week: & Learner instruction time per 5-day week: \\
Grades R-2 =23 hours & 27,5 hours \\
Grade 3 = 25 hours & \\
Grades 4-12 =27,5 hours & \\
\hline Learners choose subjects at age 16 & Either three or four skills subjects are instructed \\
& from age 14 \\
\hline Formal and informal assessment & Formal and informal assessment \\
\hline Assessment focuses on all the levels of Bloom's & Assessment focuses on the knowledge and \\
taxonomy & understanding levels of Bloom's taxonomy \\
\hline Focuses on theory & $\begin{array}{l}\text { 20\% focuses on theory, and 80\% focuses on } \\
\text { skills development }\end{array}$ \\
\hline Single-level teaching and learning & $\begin{array}{l}\text { Multilevel teaching and learning and multilevel } \\
\text { tasks }\end{array}$ \\
\hline Grade-focused learning & Straddled learning \\
\hline Limited scaffolding/unwinding/designing down & Scaffolding/unwinding/designing down and up \\
and up & often takes place \\
\hline &
\end{tabular}

The frame of reference for the curriculum development working group for learners with SID was, according to Schoeman (personal communication, 26-28 October, 2017), to compile a learning programme (that was in line with the NCS CAPS) to be rolled out in schools for learners with special educational needs as well as ordinary public schools. This programme aimed to use functional content of all subjects and provide guidance on how learners with SID could straddle subjects on either side of their specific grade in both public schools and in schools for learners with special educational needs. To address the needs of learners with SID, it was, therefore, important to adapt the curriculum and, at 
the same time, assist in the progression of SID learners to a level where they can make a contribution to society.

The importance of the abovementioned differences is that all learners, whether they are following the NCS CAPS or the SID CAPS, will be able to complete the curriculum and achieve the set outcomes. This will also give learners with SID the opportunity to progress at a special pace with the guidance of the teachers in these schools.

\section{Methodology}

In this article, we are reporting on the qualitative part of a larger research project (Louw, 2021) in which we used a participatory action research design and a social constructivist paradigm to collectively engage teachers in conversations (Masinga et al., 2016) to construct new understandings of their experiences of implementing a new curriculum. The research about the experiences of teachers during the implementation of the Life Skills CAPS for Learners with SID contributed to the community of practice that developed from the discussions and notes that were compiled by the participants. Participatory action research is a collaborative mode of inquiry that seeks to find solutions to existing problems and challenges (Ebersöhn et al., 2019).

Four schools, 13 core project groups, and 51 participants were involved in the research (see Table 2).

Purposive sampling was used to choose four schools in three provinces to be part of this phase. We distinguished between well-resourced and under-resourced schools because we also wanted to find out whether the location of the school and the resources or lack of resources had an influence on the challenges the teachers experienced. The participants of the core project groups were selected using the following criteria:

- Participants must be part of the staff of the selected pilot schools.

- Participants must teach the Life Skills CAPS for Learners with SID in their classes.

- The Life Skills CAPS for Learners with SID had to have been implemented from January 2018 or earlier.

Table 2

Participants

\begin{tabular}{ll}
\hline Schools & Group discussions \\
\hline School 1, North-West & Core Project Group 1: 5 participants \\
(Well-resourced school) & Core Project Group 2: 3 participants \\
& Core Project Group 3: 2 participants \\
& Core Project Group 4: 4 participants \\
\hline School 2, North-West & Core Project Group 1: 6 participants \\
(Under-resourced school) & Core Project Group 2: 4 participants \\
& Core Project Group 3: 5 participants \\
\hline School 3, Gauteng & Core Project Group 1: 5 participants \\
(Well-resourced school) & Core Project Group 2: 4 participants \\
& Core Project Group 3: 5 participants \\
\hline School 4, Western Cape & Core Project Group 1: 4 participants \\
(Under-resourced school) & Core Project Group 2: 2 participants \\
\hline
\end{tabular}


To generate data, we used arts-based methods. According to Weber (2014), arts-based methods enable participants to understand themselves while engaging in critical inquiry. They work together and, in the process, exchange ideas, stimulate self-reflexivity and reflect on their own and others' experiences. Arts-based research can be both scientific and artistic. In this case, it was scientific in that the research was done through empirical research, as well as artistic, given that the participants expressed their meaning through visual art forms (Richardson \& St Pierre, 2005). The collage images created by the participants led to communication with the self and with other participants taking part in the project. After creating the collages, the participants engaged in a discussion of the meaning of each artwork to give participants the opportunity to express and add meaning to their lived experiences (see Pithouse-Morgan et al., 2016).

Having completed the collages with the participants and having conducted the discussions with the core project groups, all the discussions were transcribed and coded. With the help of the researchers, the participants used thematic analysis to group the data into themes while the researchers did the theoretical analysis. Thematic analysis is a method for systematically identifying, organising, and offering insight into patterns of meaning (themes) across a data set. By focusing on meaning across a data set, thematic analysis allows the researcher to see and make sense of collective or shared meanings and experiences (Braun \& Clarke, 2012).

In qualitative research, integrity is one of the most important aspects of ethics. We, therefore, use a set of five quality criteria (process-, dialogic-, catalytic-, democratic- and outcome-validity) developed by Herr and Anderson (2014) to explain how we addressed trustworthiness in this project. In the first place, validity refers to the quality of the research process and the relationships among participants. Democratic and collaborative relationships were maintained by giving a clear explanation of the cycles and actions we used. Also, the research questions were discussed with the core project groups. Space was created within the research process for all participants to engage in and contribute to the project. The collages that the participants created and the group discussions gave each participant their own voice. Democratic validity involves the knowledge that the different core project groups can generate information that is relevant to all the participants. The participants engaged and contributed within the project by helping to analyse the transcriptions, thereby enabling mutual learning and understanding in developing knowledge. This concerns the success of the research in reaching the identified goals. Another outcome that was a result of this research is that more of the participants became aware of the use of recycling in obtaining resources for Life Skills.

The instruction to participants was to make a collage to show how they experienced the implementation of the Life Skills CAPS for Learners with SID in relation to suggested subthemes. The participants made collages by choosing pictures for each subtheme and writing a concept map on the back of the collage. A concept map assists in "compiling an inventory of denotations for the collage by listing the constituent elements systematically and cataloguing the literal meanings of the images and pictures posted on the collage" (Van Schalkwyk, 2010, p. 683). The participants were divided into groups for the making of the collages, but each participant made their own collage. The following cycles of action and reflection were followed in each group of teachers:

\section{Cycle 1}

Plan

The results from the quantitative phase already completed (Louw, 2021) were used to collaboratively develop subthemes for collages (see below). 
Act

We used an arts-based approach of making collages for data generation. Using collages to generate data encouraged the participants to connect and stimulated dialogue about their experiences in implementing the curriculum (see Masinga et al., 2016). Collage making is a "creative arts-based method in which separate images are cut from magazines, news articles and/or books and glued together to create a new image" (Raht et al., 2009, p. 229). These images symbolise the experiences of the participants and boost active involvement, critical engagement, and the ability to reflect on their experiences. The end products are a complete representation of their ideas and feelings (Van Schalkwyk, 2010).

Eleven subthemes were used:

- The creative arts curriculum

- The beginning knowledge and personal and social wellbeing curriculum

- The physical education curriculum

- Workload of teachers

- Relevance to the world of work

- Resources or a lack of resources

- The CAPS for Learners with SID-the attitude of teachers and implementing the curriculum

- Training

- Time management

- Assessment

- Difficulty of the curriculum.

\section{Observe}

The researchers observed the participants making the collages.

\section{Reflect}

Arts-based discussions were held with the different core project groups at the different schools to discuss their collages and the concept maps they had created and to explain how the collages represented their feelings about the curriculum. Solutions to the challenges they had experienced while implementing the curriculum were discussed as well.

\section{Cycle 2}

The participatory action research cycle was used again as the participants helped to analyse the transcriptions of the previous discussion and establish more themes. Knowledge and experience were shared among the participants by discussing the positive and negative aspects of each theme and giving solutions for the negative aspects. During these discussions, challenges experienced by the participants during implementation of the curriculum, as well as the solutions suggested by the participants, were discussed. With the help of the participants in the core project groups, a training manual that could be used during in-service training at the school was developed. 
As the core project groups began to understand themselves and the central issue, they realised that they had the potential to improve the situation. They decided to contribute by being a mentor school to schools that are still struggling with the implementation of the CAPS for Learners with SID.

\section{Ethical Aspects}

Ethical aspects relating to confidentiality, privacy, and autonomy were discussed with the participants in the informed consent form that they received before they started with the focus group discussion. Letters of informed consent were completed and signed by all the participants.

Ethical clearance was obtained from the North-West University. The respective provincial education departments granted permission to conduct research at the schools and to send out the questionnaires. Permission was also obtained from the principal and the school governing body of each school. Letters of informed consent were completed and signed by all the participants.

\section{Discussion of the Findings}

The three themes that emerged from the subthemes given to the participants during the making of collages focused on the participants' attitudes about the adapted curriculum, the aspects of the curriculum that influenced the implementation thereof, and its influence on the participants, respectively. Throughout the participatory research process, the contribution of social change was very important to all the participants. The participants had the opportunity to reflect with other teachers on the adapted curriculum and, by sharing their own experiences, helped other teachers to also verbalise their feelings and experiences - which led to a positive community of practice between the participants.

\section{Theme 1: The Attitude of the Participants About the New Adapted Curriculum as a Whole, and the Different Parts of the Curriculum}

It is clear from the participants' discussions that they were in favour of a functional life skills curriculum. This confirms Alwell and Cobb's (2009) opinion that there is increasing tension between the curriculum content of a typical academic-general curriculum versus the content of a functional life skills curriculum.

\section{The CAPS for Learners With SID: The Attitude of the Participants and Implementing the Curriculum}

The participants agreed with the specific objectives of the CAPS for Learners with SID, namely to provide a basis of standardised general quality education that will meet the needs of these learners and help them prepare to become more independent for life after school (DBE, 2017a).

The participants were positive about the curriculum. One of the participants even described it as a luxury. They felt that it was good to have a curriculum with lesson plans that they could use in their classes. It helped them to know what to do each week and how to plan and work according to the topics provided in the curriculum.

With the previous curriculum, it felt to me as if you're falling around; you do not really know if what you do is correct. This one, it is really, it tells you straight forward what you have to do. I think it makes it much easier. (School 3, Core Project Group 1, Participant 1)

I first felt like a small boat on a big ocean. Now I feel like a small boat firmly in someone's hand. (School 4, Core Project Group 2, Participant 1) 
Moreover, the participants felt that there was scope for differentiation in the curriculum. The meanings that the participants assigned also correspond with the aims of the Life Skills CAPS for Learners with SID to "provide a foundation of quality, standardised general education that will suit the needs of these learners and help prepare them to be more independent for life after school" (DBE, 2017a, n.p.).

\section{The Creative Arts Curriculum}

One of the specific aims of Life Skills CAPS for Learners with SID (Creative Arts) is to "give learners the opportunity to express their feelings through music, dance, drama and visual arts and to encourage them to be creative, imaginative individuals with an appreciation for art" (DBE, 2017b, n.p.). ${ }^{3}$

Figure 1 illustrates the opinion of a participant who was very positive about the creative arts curriculum.

\section{Figure 1}

\section{Collage 1}

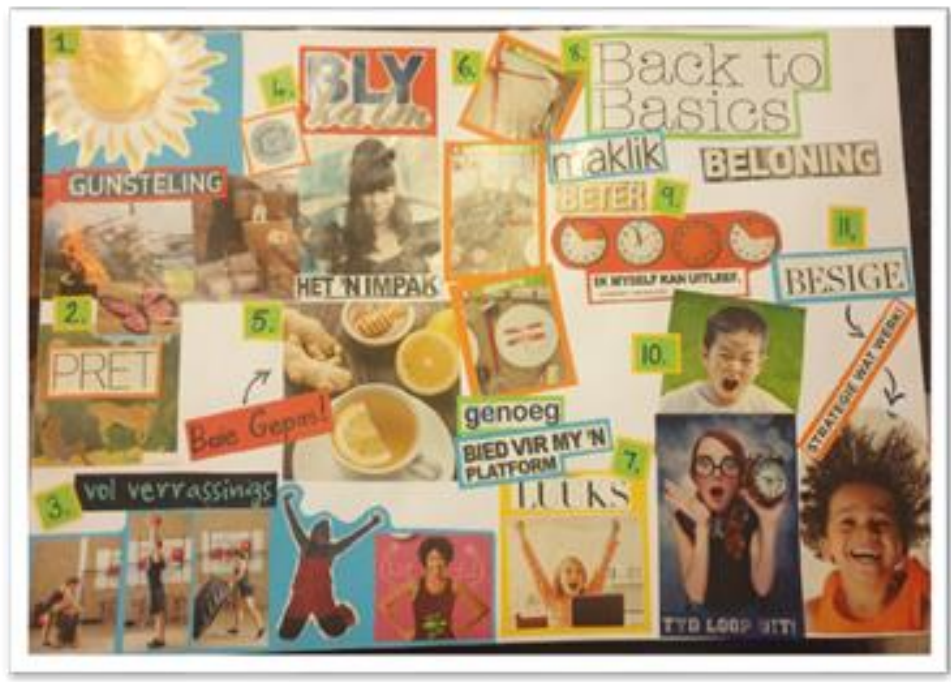

In Figure 1, Picture 1, it is shown that the creative arts curriculum was the participant's favourite ("gunsteling") curriculum. Although the participants' opinions differed, most of them were very positive about the creative arts curriculum. This participant said that the specific curriculum was her absolute favourite of all the different curricula, whereas another participant mentioned that it was the curriculum she "stole" time from to do other work.

Researcher: Is it your favourite curriculum of all the different curricula or just your favourite of the life skills curricula?

No, of all the curricula. It is really, yes, you can really feel you are putting your whole life into it. (School 1, Core Project Group, Participant 1)

Let me put it like this: for me it was always, the children enjoyed it, it was nice, but for me, as I am a department head, it was usually the curriculum that I, with physical education, the first curriculum that I did not really finish, as I spent more time on Life Skills-Beginning

\footnotetext{
${ }^{3}$ Although this document is available by request from the Department of Basic Education, it is still under review by the Department, and will only be generally available when it is declared a policy.
} 
3)

\section{The Beginning Knowledge and Personal and Social Wellbeing Curriculum}

The fact that participants were positive about the skills and values incorporated in the curriculum is confirmed by the specific aims of the Life Skills SID curriculum given that the document states that the subject encourages learners to acquire and practise life skills that will assist them to become independent and effective in responding to life's challenges, and to play an active and responsible role in society within their personal capability (DBE, 2017a). Figure 2, Picture 2 shows the opinion of a participant about the beginning knowledge and personal and social wellbeing curriculum.

\section{Figure 2}

\section{Collage 2}

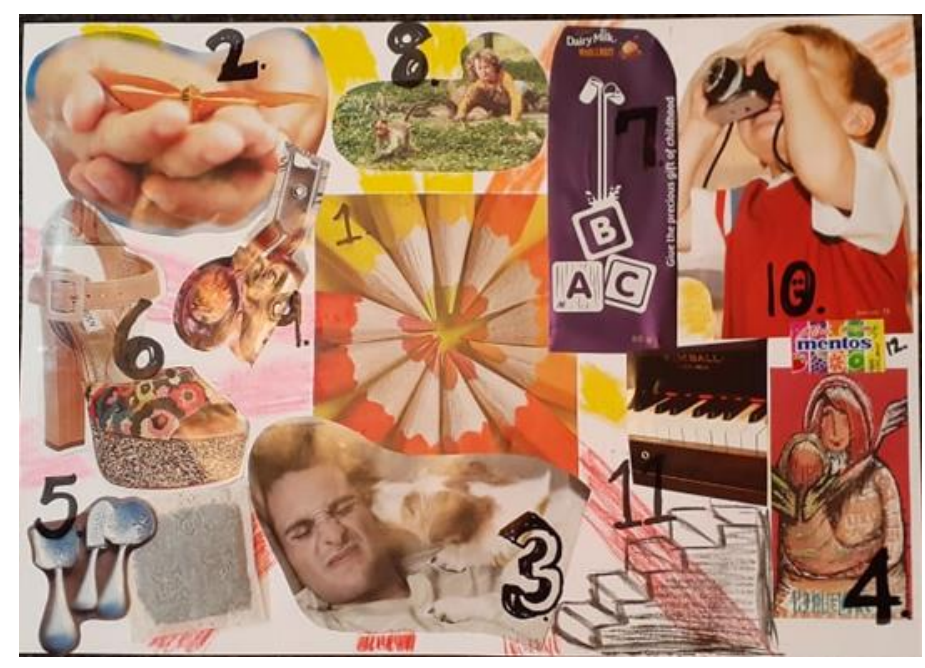

Figure 2, Picture 2 shows two hands holding a butterfly, indicating that this curriculum is teaching learners different skills. The participants were positive about the skills and values incorporated into this curriculum. They did not like all the topics that were prescribed but were positive about the fact that the curriculum described in detail what should be taught each year.

It just felt, if I work through this, it would feel like, it is almost like a hug. I don't know how to say it. A hug makes you feel good; it feels to me you did everything you can. It helps the teacher, it helps the child, and it makes you feel better. Especially with personal and social wellbeing. Our children are, some of the small children are poor. They don't learn all the knowledge they need at home. (School 2, Core Project Group 4, Participant 2)

\section{The Physical Education Curriculum}

The Life Skills CAPS for Learners with SID (Physical Education) focuses on perceptual and locomotive development, rhythm, balance, and laterality. The focus in the early years is on games and activities that form the basis for later participation in sports. Physical growth, development, recreation, and play are all emphasised (DBE, 2017c). ${ }^{4}$

\footnotetext{
${ }^{4}$ Although this document is available by request from the Department of Basic Education, it is still under review by the Department, and will only be generally available when it is declared a policy.
} 
The participants were positive about this curriculum although they mentioned that they missed lesson plans, which were not included in the curriculum.

I think I can, but I have to give a lot of guidance to colleagues who doesn't understand it or doesn't have the experience to understand what they can do with the information in the curriculum. (School 3, Core Project Group 2, Participant 2)

The participants also felt that if the school had sports practice during school hours, the learners (and teachers) did not always recognise the need for doing physical education as well.

Although the implementation of the Life Skills CAPS for Learners with SID was, in general, successful, there are still some problems that need to be addressed such as time management, the workload of teachers, resources, and assessment. A positive aspect is that most of the participants agreed that it was good to have a structured curriculum that gave teachers guidelines and provided them with lesson plans so that they knew what was expected from them. Moreover, the fact that most schools for learners with SID now use the same CAPS for Learners with SID creates a community of teachers working together. The participants felt that the successful implementation of the curriculum depended a lot on the attitude of the teachers; if the teacher was fully committed, the curriculum would be a success.

\section{Theme 2: Aspects of the Curriculum That Have an Influence on the Implementation of the Curriculum}

Particular aspects of the curriculum have an influence on the successful implementation thereof, such as its relevance to the world of work, resources, training, assessment, and the difficulty of the curriculum.

\section{Relevance to the World of Work}

The participants had different opinions about the world of work. They all agreed that it was very important to include this topic in the life skills curriculum but mentioned that it was included only in the senior phase of the curriculum (DBE, 2017a).

The DBE felt strongly that the world of work topics must be aimed at preparing the learner for life after school. The content should be adapted to enable the reality that the learner experiences after school and, therefore, was developed to make learners with a severe intellectual disability "street smart" and teach them other coping mechanisms to be fully included in their communities and society (DBE, 2017a).

I really think it is important because even if it is only one child you can equip with the necessary skills to one day go and do something outside the school, that is one child you have helped. Each child, in the end, needs skills to generate a future for himself. (School 4, Core Project Group 2, Participant 1)

One participant mentioned that it was also a factor whether a learner was really severely disabled and would never manage to have a job they could do independently. Other participants felt that the elective subjects played a more important role in the world of work and felt that the beginning knowledge curriculum should include more ways for learners to acquire skills in the world of work.

\section{Resources}

Poor resources (or a lack of resources) can limit the performance of even the best teacher, and undermine learners' efforts to focus on teaching and learning (Furiwai \& Singh-Pillay, 2020). This is in 
line with the finding of Onwu and Stoffels (2005) that a lack of resources adversely affected teachers' involvement in practical work. Figure 3, Picture 6 shows the opinion of a participant about the resources at her school.

\section{Figure 3}

\section{Collage 3}

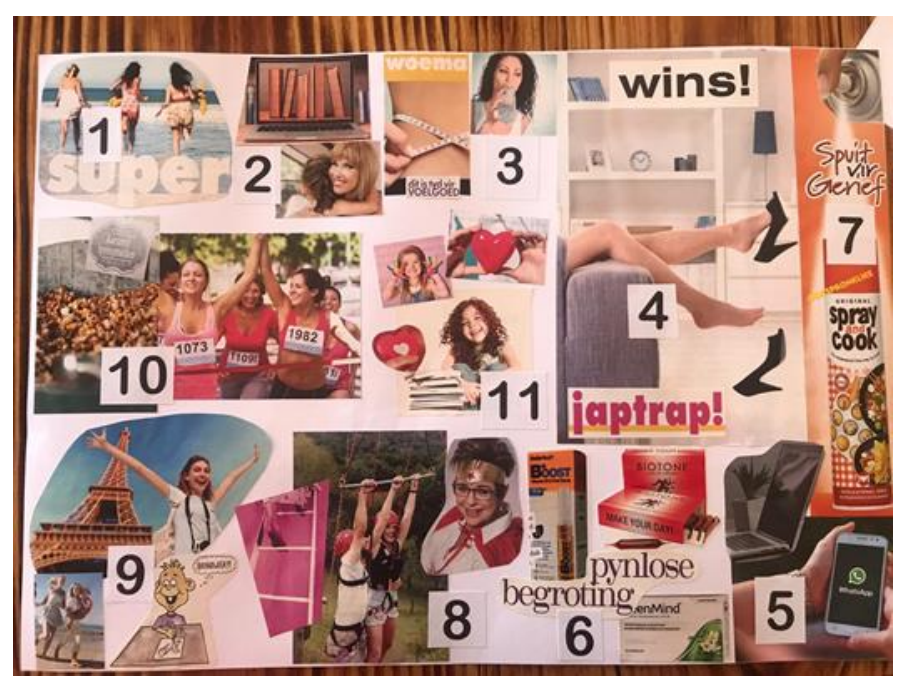

Figure 3, Picture 6 shows that the participant experienced the budget for resources at her school as painless ("pynlose begroting"). In the discussion of this aspect, there was a big difference among the schools. The participants from well-resourced schools felt that they were blessed with ample resources at school and, if they did their planning well, they could use waste or recycled material to do the work, especially in creative arts. Picture 6 in Figure 3 shows empty pill boxes, indicating that a teacher can use recycled material for resources.

From the day I started teaching, we saved everything. I saved my used teabags, you saved eggshells, and I think if early childhood teaching is in your blood, then you do it. You save everything. (School 4, Core Project Group 4, Participant 3)

The participants felt that the physical education curriculum needed some resources and that it would be difficult to successfully implement the curriculum if teachers did not have the prescribed resources.

\section{Training}

Molapo and Pillay (2018) emphasised that intensive teacher training is vital in implementing a new curriculum. Without quality training, teachers will find it difficult to successfully implement the curriculum.

There were different opinions about the training of teachers regarding the curriculum. The participants who had the privilege of having two of the curriculum writers at their school, felt that they had an advantage because all the challenges they experienced could be solved by talking to the curriculum writers. They felt positive about the training they had received from the DBE, while participants teaching at other schools felt that they had been thrown into the deep end given that they had first received training two years after they had started to implement the curriculum. Some schools failed to implement the curriculum due to the lack of training. Also, not all the facilitators providing the training were up to standard, and the participants felt that they had wasted valuable time. 
The proposal of some schools acting as mentor schools to schools that struggled to implement the curriculum was seen as a good idea.

And I think if everybody helps one another, it can only get better. It doesn't help if one school is doing everything correct and another school is doing nothing; in the end, it is the child who is suffering. (School 1, Core Project Group 1, Participant 1)

The participants felt that the in-service training they had received at their own schools was more valuable than the training the DBE had provided. They stated that there had been too many teachers at the various training points and the teachers did not have the courage to ask questions because it took a long time to answer all the questions.

That is how I see my colleagues ... each time I didn't understand or didn't know what is going on, there was someone who helped me or supported me. (School 2, Core Project Group 4, Participant 3)

\section{Assessment}

As learners function at different levels, assessment, recording, and reporting must provide for the level of each individual learner to be reflected-as set out in the individual support plan to be developed at the beginning of the year in accordance with the procedures set out in the National Strategy on Screening, Identification, Assessment and Support of 2014 (DBE, 2014b).

The participants were positive about the fact that the assessment was provided in the curriculum. Some pointed out that there were too many assessments that should be done, whereas others felt that assessment showed them exactly how the learners were progressing.

It is black and white; there is no grey area. It tells you straight out what you have to assess. You can still compile your own rubric within the assessment. It makes it more personal. (School 3, Core Project Group 4, Participant 3)

The participants agreed that it was important to use rubrics to do assessment. Some of them stated that they had to succeed in implementing the curriculum first before starting to compile rubrics, and that they struggled with assessment.

\section{Difficulty of the Curriculum}

The degree of difficulty of the curriculum provoked a wide response. Learners who need high levels of support struggle to master the content of the curriculum, especially in the beginning knowledge and personal and social wellbeing curriculum (DBE, 2017a). Here, differentiation, according to the participants, is the answer.

The opinions of the participants differed on this point. Those participants who had implemented the curriculum successfully did not have a problem with the difficulty of the curriculum. However, participants who were still struggling with implementation felt that the curriculum was too difficult for learners with severe barriers to learning. The participants said that when they followed the curriculum for the second or third year, they managed to do more work with the learners because they had the experience of what worked and what not, which helped them to cope with the difficulty of the curriculum. It is also important to know that the provision of appropriate support services is essential for learners who experience barriers to learning to gain equal access (DBE, 2017a). 
With experience, the learners will find it easier. The more comfortable I am with presenting the curriculum, the easier it will be to teach the CAPS to the children. (School 1-, Core Project Group 2, Participant 1)

Looking at Theme 2, we concluded that the above five aspects caused difficulty in the implementation of the curriculum and the participants had strong opinions about them. These aspects have to be addressed by the school management teams as well as the different provincial education departments.

\section{Theme 3: The Influence of the Implementation of the Curriculum on the Teacher on a Personal Level}

The two aspects that have a significant influence on teachers on a personal level are workload and time management.

\section{Workload of Participants}

Figure 4 , Picture 4 shows the perspective of a participant about the workload she experienced during the implementation of the curriculum.

\section{Figure 4}

\section{Collage 4}

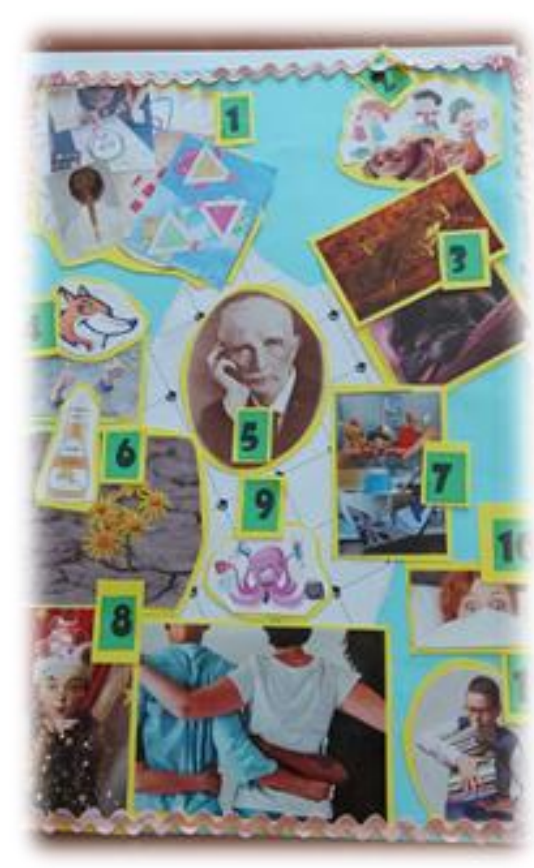

Picture 4 is a picture of a fox. In Afrikaans the proverb is, "Dit is die klein jakkalsies wat die wingerd verwoes," meaning that it is the little things that happen every day in class that increase the workload of teachers. A concept map for Collage 4 was also included to show what was written by the participant about Picture 4 (see Figure 5). 


\section{Figure 5}

\section{Example of a Concept Map}

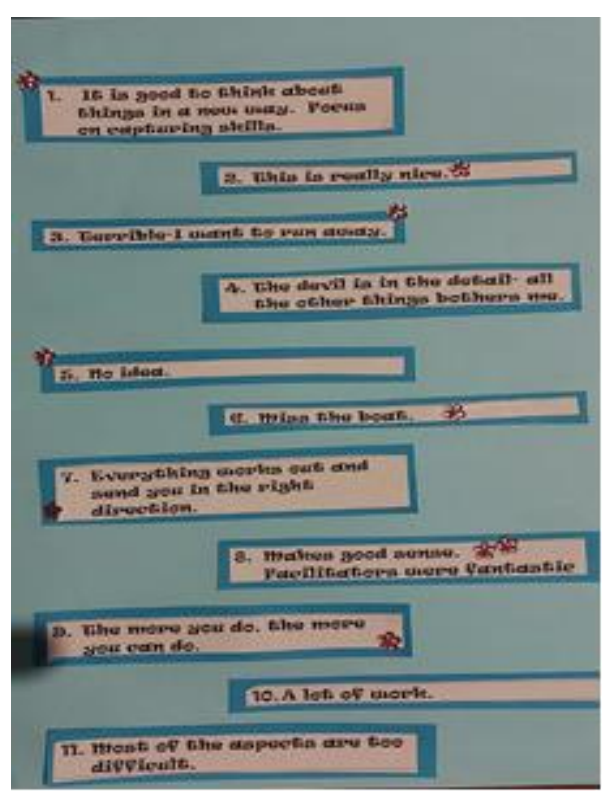

The participants felt that the new CAPS for Learners with SID influenced the workload of the teacher but, if they managed to work hard in the first year of implementation, the workload was less in the following years. They agreed that the diverse learners in each class had an impact on the workload and working out lesson plans because differentiation must be included in the planning. All the participants said they used their weekends to do their weekly and daily planning. The participants in the rural schools, who did not have all the resources needed, such as wi-fi and interactive whiteboards, felt that the workload had a greater impact on their personal time. According to van Tonder and Fourie (2015), research indicates that $28 \%$ of teachers in New Zealand have considered leaving the teaching profession due to the workload. However, participants who had previously worked at a public ordinary school felt that with the new CAPS for Learners with SID, they had much more personal time.

I now have much more personal time. I do it in a jiffy. It feels as if I can kick off my shoes and watch TV programmes. It makes it much easier. (School 3, Core Project Group 2, Participant 2)

The participants at one of the schools felt that because two of the curriculum writers of the CAPS for Learners with SID were employed at their school, they had the advantage of getting more personal information and help.

We got a lot of support from you who had written the curriculum. We were in the privileged position to know, okay, you are struggling with something, there is someone nearby who can help you with the problem. (School 1, Core Project Group 4, Participant 3)

\section{Time Management}

Teachers experience pressure from the DBE, the management team, and parents to ensure accurate record keeping. Because this is an ongoing process, it leads to teachers spending much time on administrative duties. This can lead to teaching time being reduced and workload increase (van Tonder $\&$ Fourie, 2015. The participants felt that the curriculum had been written in such a way that they were able to manage their time successfully. 
I am happy with the time management. I feel free if I realise there is extra time for the children to daydream and still finish their activity in time. (School 2, Core Project Group 4, Participant 4)

However, one participant, who was a department head, said she struggled to manage her time between her responsibilities and the learners in her class. The participants stressed the fact that proper time management would not be possible without the help of their class assistants. Participants who had more than 15 learners in their classes struggled with time management.

To summarise the findings of the three themes, we want to focus on the following:

- The participants were very positive about the Life Skills CAPS for Learners with SID, especially the Beginning Knowledge and Personal and Social Wellbeing programme, but they were negative about the implementation of the curriculum.

- Personal factors, such as workload and time management, made the participants negative because they have to use their personal time and weekends to complete their preparation.

- A lack of resources, especially the lack of handbooks developed specifically for the curriculum, is a big problem.

- Training was not done in all the provinces, and the participants needed proper training to successfully implement the curriculum.

- It is still better to have a structured curriculum with lesson plans to help teachers prepare for their teaching and learning, therefore, the participants were positive about the curriculum.

\section{Limitations}

The implementation of the Life Skills CAPS for Learners with SID only started in 2018 and, therefore, published research on it is still limited. COVID-19 regulations forbid schools to allow researchers to come to schools, consequently, some focus group discussions were done by using Zoom. This method, which restricts the time of a meeting to 40 minutes, influenced the personal relationships we could build with the participants of some core project groups.

\section{Conclusion}

We wanted to answer the question, "How successful is the implementation of the Life Skills CAPS for Learners with SID in schools for learners with special educational needs?" We conclude that, although there are many challenges in successfully implementing the CAPS for Learners with SID, more than half of the participating teachers were positive about the fact that, for the first time, there was a structure according to which teachers could work, with fixed guidelines and weekly planning they could use. It is also clear that the Life Skills CAPS for Learners with SID does not dampen teachers' creativity; to the contrary, there is much more room for innovation and originality. The fact that electives prepare learners from 14 to 18 years of age for the world of work and that, in some cases, they can obtain a certificate of competency, contributes to the success of the CAPS for Learners with SID.

If we look at the long-term change potential of this participatory research, it is evident that it will contribute to social change on all the different levels of this partnership. We gained insight into the challenges the participants experienced by listening to their reflections during the discussions. According to them, their positive attitude will have an effect on the way they teach the curriculum, which will result in motivated learners and happier parents. The skills and values indicated in the 
curriculum will also contribute to the quality of life of the learners and help them to make a positive contribution to the community.

Based on the results of the qualitative focus group discussions with the core project groups, the findings were used to do a qualitative exploration with the participants to collaboratively develop a training manual for teachers and to inform future curriculum developers.

\section{References}

Alwell, M., \& Cobb, B. (2009). Functional life skills curricular interventions for youth with disabilities: A systematic review. Career Development for Exceptional Individuals, 32(2), 82-93. https://doi.org/10.1177/0885728809336656

American Psychiatric Association. (2020). What is intellectual disability? https://www.psychiatry.org/patients-families/intellectual-disability/what-is-intellectual-disability

Braun, V., \& Clarke, V. (2012). Thematic analysis. In H. Cooper (Ed.), APA handbook of research methods in psychology, Vol. 2: Research designs, quantitative, qualitative, neuropsychological, and biological (pp. 57-71). APA.

Chowdhury, P. R. (2011). The right to inclusive education of persons with disabilities: The policy and practice implications. Asia-Pacific Journal on Human Rights and the Law, 12(2), 1-35. https://doi.org/10.1163/138819011X13215419937869

Department of Basic Education. (2011). Curriculum and assessment policy statement: English life skills. Foundation phase Grades $R-3$. https://www.education.gov.za/Portals/0/CD/National\%20Curriculum\%20Statements\%20and\%20 Vocational/CAPS\%20Life\%20Skills\%20\%20English\%20 \%20Gr\%20R-3\%20FS.pdf?ver=2015-01-27$\underline{162204-953}$

Department of Basic Education. (2014a). First writing session for the development of a skills and vocational learning programme [Unpublished report].

Department of Basic Education. (2014b). National strategy on screening, identification, assessment and support. https://wcedonline.westerncape.gov.za/Specialised-ed/documents/SIAS-2014.pdf

Department of Basic Education. (2017a). Differentiated curriculum and assessment policy statement: Life skills [Draft, unpublished].

Department of Basic Education. (2017b). Differentiated curriculum and assessment policy statement: Life skills: Creative arts [Draft, unpublished].

Department of Basic Education. (2017c). Differentiated curriculum and assessment policy statement: Life skills: Physical education [Draft, unpublished].

Department of Education. (1997). Curriculum 2005: Lifelong learning for the 21st century.

Department of Education. (2001). Education White Paper 6: Special needs education, building an inclusive education and training system. https://www.gov.za/sites/default/files/gcis document/201409/educ61.pdf

Ebersöhn, L., Eloff, I., \& Ferreira, R. (2019). First steps in action research. In K. Maree (Ed.), First steps in research (3rd ed., pp. 133-159). van Schaik.

Engelbrecht, P. (2020). Inclusive education: Developments and challenges in South Africa. Prospects, 49, 219-232. https://doi.org/10.1007/s11125-020-09499-6

Freire, P. (2005). Pedagogy of the oppressed (M. B. Ramos, Trans.). Continuum. 
Furiwai, S., \& Singh-Pillay A. (2020). The views and experiences of Grade 10 life sciences teachers on the compulsory practical examination. Perspectives in Education, 38(1), 242-254. http://dx.doi.org/10.18820/2519593X/pie.v38i1.17

Herr, K., \& Anderson, G. L. (2014). The action research dissertation. SAGE.

Ingvarson, L., Kleinhenz, E., Neavis, A., Barwick, H., Carthy. I., \& Wilkinson, J. (2006). Secondary teacher workload study: Report. Australian Council for Educational Research.

Louw, J. G. (2021). Die implementering van die lewensvaardigheid kurrikulum en assesseringsbeleidsverklaring vir verstandelik erg gestremde leerders in skole vir leerders met spesiale onderwysbehoeftes [Unpublished doctoral thesis]. North-West University, South Africa.

Mahmoudi, A. A. K., \& Babae, A. (2014). Paulo Freire critical pedagogy and its implications in curriculum planning. Journal of Education and Practice, 5(14), 178-186. https://www.iiste.org/Journals/index.php/JEP/article/view/12993

Masinga, L., Myende, P., Marais, A., Singh-Pillay, A., Kortjass, M., Chirikure, T., \& Mweli, P. (2016). "Hear our voices": A collective arts-based self-study of early-career academics on our learning and growth in a research-intensive university. Educational Research for Social Change, 5(2), 117-135. http://dx.doi.org/10.17159/2221-4070/2016/v5i2a8

Mitchell, D. (2015). Inclusive education is a multi-faceted concept. Center for Educational Policy Studies Journal, 5(1), 9-30. https://files.eric.ed.gov/fulltext/EJ1128952.pdf

Molapo, M. R., \& Pillay, V. (2018). Politicising curriculum implementation: The case of primary schools. South African Journal of Education, 38(1), 1-9. https://doi.org/10.15700/saje.v38n1a1428

Onwu, G. O. M., \& Stoffels, N. (2005). Instructional functions in large, under-resourced science classes: Perspectives of South African teachers. Perspectives in Education, 23(3), 79-91. https://www.researchgate.net/publication/265074746 Instructional functions in large underresourced science classes Perspectives of South African teachers

Pithouse-Morgan, K., Naicker, I., Pillay, D., Masinga, L., \& Hlao, T. (2016). "Sink or swim?": Learning from stories of becoming academics within a transforming university terrain. South African Journal of Higher Education, 30(1), 1-20. https://doi.org/10.20853/30-1-561

Raht, D., Smith, J., \& MacEntee, K. (2009). Engaging youth in addressing HIV \& AIDS: Creative and participatory methods in the classroom. In C. Mitchell \& K. Pithouse (Eds.), Teaching and HIV \& AIDS (pp. 219-236). MacMillan.

Richardson, L., \& St Pierre, E. A. (2005). Writing: A method of inquiry. In N. K. Denzin \& Y. S. Lincoln (Eds.), The SAGE handbook of qualitative research (3rd ed., pp. 959-978). SAGE.

South African Schools Act 841996. https://www.gov.za/sites/default/files/gcis document/201409/act84of1996.pdf

UNESCO. (1994). The Salamanca statement and framework for action on special needs education. https://www.right-to-education.org/sites/right-to-education.org/files/resourceattachments/Salamanca Statement 1994.pdf

United Nations. (2006). Convention on the rights of persons with disabilities (A/RES/61/106, Annex. I). https://www.refworld.org/docid/4680cd212.html

Van Schalkwyk, G. J. (2010). Collage life story elicitation technique: A representational technique for scaffolding autobiographical memories. The Qualitative Report, 15(3), 675-695. https://nsuworks.nova.edu/tar/vol15/iss3/11 
van Tonder, D., \& Fourie, E. (2015). The effect of job demands and a lack of job resources on South African educators' mental and physical resources. Journal of Social Sciences, 1(41), 65-77. https://doi.org/10.1080/09718923.2015.11893395

Walton, E., \& Rusznyak, L. (2014). Affordances and limitations of a special school practicum as a means to prepare pre-service teachers for inclusive education. International Journal of Inclusive Education, 18(9), 957-974. https://doi.org/10.1080/13603116.2013.872203

Weber, S. (2014). Arts-based self-study: Documenting the ripple effect. Perspectives in Education, 32(2), 8-20. https://iournals.ufs.ac.za/index.php/pie/article/view/1855

Western Cape Forum for Intellectual Disability v. Government of the Republic of South Africa and Another (Western Cape High Court 2010). http://www.saflii.org/za/cases/ZAWCHC/2010/544.pdf 